\title{
Phytochemical Analysis and Antioxidant Potential of Rhizome Extracts of Curcuma amada Roxb and Curcuma caesia Roxb
}

\author{
Mamta Yadav*, K. Kalyan Saravanan \\ Bhagwant University, Sikar Rd, Ajmer, Rajasthan 305004
}

\begin{abstract}
Plants have served human beings as a natural source for treatments and therapies from ancient times, amongst them medicinal h erbs have gain attention because of its wide use and less side effects. In the recent years plant research has increased throughout the world and a huge amount of evidences have been collected to show immense potential of medicinal plants used in various traditional systems. Curcuma amada Roxb ( $C$. amada, Zingiberaceae) is a perennial, rhizomatous, aromatic herb commonly known as Amada or Amahaldi or mango ginger due to the raw mango-like aroma of the rhizome. It is used medicinally as a coolant, astringent and to promote digestion. Curcuma caesia Roxb (C. caesia, Zingiberacea) is a perennial herb with bluish black rhizomes commonly known as black turmeric and are traditionally used in treatment of various ailments and metabolic disorders like leukoderma, asthma, tumours, piles, bronchitis, etc. in Indian system of medicine. The aim of the present study was to evaluate in vitro antioxidant activities and qualitative and quantitative phytochemical analysis of rhizome of $C$. amada and C. caesia collected from Bhopal region of Madhya Pradesh. Qualitative analysis of various phytochemical constituents and quantitative analysis of total phenolics and flavonoids were determined by the well-known test protocol available in the literature. The in vitro antioxidant activity of methanolic extract of the rhizome was assessed against DPPH assay method using standard protocols. Phytochemical analysis revealed the presence of phenols, flavonoids, tannins, saponins, alkaloids. The total flavonoids content of methanolic rhizomes extract of $C$. caesia and $C$. amada was found to be 2.752 and $2.920 \mathrm{mg} / 100 \mathrm{mg}$ respectively. The activities of methanolic rhizomes extract against DPPH assay method were concentration dependent with IC 50 values of ascorbic acid and extracts 14.11 and $170.81,63.69 \mu \mathrm{g} / \mathrm{ml}$ respectively. The diverse array of phytochemicals present in the plant thus suggests its therapeutic potentials which may be explored in drug manufacturing industry as well as in traditional medicine.
\end{abstract}

Keywords: Curcuma amada, Curcuma caesia, Zingiberacea, Phytochemical analysis, Antioxidant

Article Info: Received 11 June 2019; $\quad$ Review Completed 06 Aug 2019; Accepted 19 Aug 2019; Available online 15 Sep 2019

\section{Cite this article as:}

Mata Yadav M, Saravanan KK, Phytochemical Analysis and Antioxidant Potential of Rhizome Extracts of Curcuma amada Roxb and Curcuma caesia Roxb, Journal of Drug Delivery and Therapeutics. 2019; 9(5):123-126 http://dx.doi.org/10.22270/jddt.v9i5.3609

\section{*Address for Correspondence:}

Mamta Yadav, Bhagwant University, Sikar Rd, Ajmer, Rajasthan 305004

\section{INTRODUCTION}

Indian Medicinal plants are considered a vast source of several pharmacologically active principles and compounds, which are commonly used in home remedies against multiple ailments ${ }^{1}$. The genus Curcuma is a well known spice of India. It is also called Haldi and more than 200 species and subspecies of it is found all across the world. One of which is Curcuma caesia Family: Zingiberaceae. It is also known as Kali Haldi. It is an erect rhizomatous herb with large leaves. Fresh rhizomes are aromatic with intense camphoraceous odour and are applied externally to sprain and bruises ${ }^{2}$. $C$. caesia is native to Northeast and Central India. It is also sparsely found in Papi hills of East Godavari, the root hills of the Himalayas and North Hill forest of Sikkim. The rhizomes of $C$. caesia have a high economic importance owing to its putative medicinal properties. The rhizomes are used in the treatment of hemorrhoids, leprosy, asthma, cancer, epilepsy, ISSN: 2250-1177 fever, wound, vomiting, menstrual disorder, smooth muscle relaxant activity, anthelmintic, aphrodisiac, inflammation, gonorrheal discharges, etc ${ }^{3}, 4$. C. Caesia contain maximum curcuminoids, oil content, flavonoids, phenolics, different important amino acids,protein and high alkaloid content which reveals that the presence of these bioactive secondary metabolites correlates with the medicinal uses of C. Caesia as fragrances, flavouring and many important useful pharmaceutical products ${ }^{5}$. C. amada Roxb (Zingiberaceae) is a perennial, rhizomatous, aromatic herb commonly known as Amada or Amahaldi or mango ginger due to the raw mangolike aroma of the rhizome. It is found wild as well as in cultivation in various parts of world. In India, it is cultivated in Gujarat, West Bengal, Uttar Pradesh, Karnataka, Tamil Nadu, Konkan and in the hills of Western coast of India but it is not cultivated anywhere commercially ${ }^{6}$. Mango ginger is used medicinally as a coolant, astringent and to promote 
digestion. In addition, to this, it is used as a basic ingredient in pickles, preserves, candies, sauces, curries and salads 7,8 . Its rhizome has carminative properties as well as being useful as a stomachic ${ }^{9}$. Its rhizome has traditionally been used for healing of wounds, cuts and itching ${ }^{10}$. It possesses antifungal, anti-inflammatory, analgesic, anticancer and antihyperglyceridemic properties ${ }^{11}$. The rhizome extracts of Curcuma were observed to be potent antimutagenic properties based on its antioxidative activity ${ }^{12}$. Its rhizomes are used for the manufacture of oleoresin, essential oil, etc 13 . It reported to contain ocimene, dihydro-ocimene, $\alpha$-pinene, $\alpha$-curcumene, $\beta$-curcumene, linalool, cuminyl alcohol, ketoalcohol, camphor, turmerone, linalyl acetate, safrole, curcumin, myristic acid, car-3-ene, myrcene, 1,8-cineol, limonene and perillene ${ }^{14}$. The rhizomes are used by the tribals of Madhya Pradesh for the management of diabetes mellitus ${ }^{15}$. Antioxidants present in vegetables, beverages and fruits were providing health-promoting ingredients in human diet and also responsible for the prevention and treatment of radical-mediated disorderness ${ }^{16}$. The usefulness of artificial antioxidants such as butylated hydroxytoulene (BHT) and butylated hydroxyanisole (BHA) are under scrutiny due their suspected role in carcinogenesis ${ }^{17}$. Thus, there is an urgent need of natural additives as potential antioxidants having an important role in preventing a variety of stress-related diseases ${ }^{18}$. The present study was focused to evaluate the phytochemical analysis and anti oxidant activity of rhizomes of C. amada and $C$. caesia.

\section{MATERIALS AND METHODS}

\section{Plant material}

Rhizome of C. Caesia and C. Amada were collected from local area of Bhopal (M.P.) in the month of March, 2019.

\section{Defatting of plant material}

Powdered plant material of C. Caesia and C. Amada were shade dried at room temperature. The shade dried plant material was coarsely powdered and subjected to extraction with petroleum ether using maceration method. The extraction was continued till the defatting of the material had taken place.

\section{Extraction by maceration process}

265gm of C. Caesia and 310 gm C. Amada dried Rhizome were exhaustively extracted with different solvent (chloroform, ethyl acetate, methanol and water) using maceration method. The extract was evaporated above their boiling points. Finally the percentage yields were calculated of the dried extracts ${ }^{19,20}$.

\section{Chemical reagents}

All the chemicals used in this study were obtained from $\mathrm{Hi}$ Media Laboratories Pvt. Ltd. (Mumbai, India), Sigma Aldrich Chemical Co. (Milwaukee, WI, USA), SD Fine-Chem. Ltd. (Mumbai, India) and SRL Pvt. Ltd. (Mumbai, India).All the chemicals used in this study were of analytical grade.

\section{Phytochemical screening}

Phytochemical screening to detect the presence of bioactive agents was performed by standard procedures ${ }^{21,22}$. After the addition of specific reagents to the solution, the tests were detected by visual observation of color change or by precipitate formation.

\section{Total flavonoid contents}

The total flavonoid content was determined using the method of Olufunmiso et al $23.1 \mathrm{ml}$ of $2 \% \mathrm{AlCl} 3$ methanolic solution was added to $3 \mathrm{ml}$ of extract or standard and allowed to stand for $60 \mathrm{~min}$ at room temperature; the absorbance of the reaction mixture was measured at $420 \mathrm{~nm}$ using UV/visible spectrophotometer The content of flavonoids was calculated using standard graph of quercetin and the results were expressed as quercetin equivalent (mg/g).

\section{Antioxidant activity of extract using DPPH method}

DPPH scavenging activity was measured by modified $\operatorname{method}^{23}$. DPPH scavenging activity was measured by the spectrophotometer. Stock solution ( $6 \mathrm{mg}$ in $100 \mathrm{ml}$ methanol) was prepared such that $1.5 \mathrm{ml}$ of it in $1.5 \mathrm{ml}$ of methanol gave an initial absorbance. Decrease in the absorbance in presence of sample extract at different concentration (10$100 \mu \mathrm{g} / \mathrm{ml}$ ) was noted after 15 minutes. $1.5 \mathrm{ml}$ of DPPH solution was taken and volume made till $3 \mathrm{ml}$ with methanol, absorbance was taken immediately at $517 \mathrm{~nm}$ for control reading. $1.5 \mathrm{ml}$ of DPPH and $1.5 \mathrm{ml}$ of the test sample of different concentration were put in a series of volumetric flasks and final volume was adjusted to $3 \mathrm{ml}$ with methanol. Three test samples were taken and each processed similarly. Finally the mean was taken. Absorbance at zero time was taken for each concentration. Final decrease in absorbance was noted of DPPH with the sample at different concentration after 15 minutes at $517 \mathrm{~nm}$. The percentage inhibition of free radical DPPH was calculated from the following equation: $\%$ inhibition $=[$ (absorbance of control absorbance of sample)/absorbance of control] $\times 100 \%$. Though the activity is expressed as $50 \%$ inhibitory concentration (IC50), IC50 was calculated based on the percentage of DPPH radicals scavenged. The lower the IC50 value, the higher is the antioxidant activity.

\section{RESULTS AND DISCUSSION}

The crude extracts so obtained after each of the maceration extraction process were concentrated on water bath by evaporation the solvents completely to obtain the actual yield of extraction. The yield of extracts obtained from the rhizomes of the plants using petroleum ether, chloroform, ethyl acetate, methanol and water as solvents are depicted in the Table 1 . The results of qualitative phytochemical analysis of the crude powder rhizomes of $C$. caesia and $C$. amada are shown in Table $2 \& 3$. methanolic and aqueous extracts of rhizomes sample of $C$. caesia and $C$. amada showed the presence of flavonoids, phenols, tannins, carbohydrate, glycosides and proteins but in chloroform extracts all phytoconstituents was absents and flavonoids was present in C. amada extract.

Table 1 Results of percentage yield of rhizomes extracts

\begin{tabular}{|c|c|c|c|c|c|}
\hline \multirow{2}{*}{ Plant Name } & \multicolumn{5}{|c|}{ Percentage yield (\%) } \\
\cline { 2 - 6 } & Pet. Ether & Chloroform & Ethyl acetate & Methanol & Water \\
\hline C. caesia & 0.780 & 1.91 & 0.426 & 1.83 & 3.13 \\
\hline C. amada & 0.875 & 2.90 & 1.04 & 2.66 & 3.15 \\
\hline
\end{tabular}


Table 2 Phytochemical evaluation of $C$. caesia rhizomes extracts

\begin{tabular}{|c|c|c|c|c|c|}
\hline S. No. & Constituents & $\begin{array}{c}\text { Chloroform } \\
\text { extract }\end{array}$ & $\begin{array}{c}\text { Ethyl acetate } \\
\text { extract }\end{array}$ & $\begin{array}{c}\text { Methanol } \\
\text { extract }\end{array}$ & $\begin{array}{c}\text { Aqueous } \\
\text { extract }\end{array}$ \\
\hline 1. & Alkaloids & - & - & - & - \\
\hline 2. & Glycosides & - & - & - & - \\
\hline 3. & Flavonoids & - & - & + & + \\
\hline 4. & Saponins & - & - & + & + \\
\hline 5. & Phenolics & - & - & - & - \\
\hline 6. & Amino Acids & - & - & - & - \\
\hline 7. & Carbohydrate & + & + & + & + \\
\hline 8. & Proteins & - & - & + & + \\
\hline 9. & Diterpenes & + & + & + & + \\
\hline
\end{tabular}

(+) Indicates 'Presence'; (-) Indicates 'Absence'

Table 3 Phytochemical evaluation of $C$. amada rhizomes extracts

\begin{tabular}{|c|c|c|c|c|c|}
\hline S. No. & Constituents & $\begin{array}{c}\text { Chloroform } \\
\text { extract }\end{array}$ & $\begin{array}{c}\text { Ethyl acetate } \\
\text { extract }\end{array}$ & $\begin{array}{c}\text { Methanol } \\
\text { extract }\end{array}$ & $\begin{array}{c}\text { Aqueous } \\
\text { extract }\end{array}$ \\
\hline 1. & Alkaloids & - & - & - & - \\
\hline 2. & Glycosides & - & - & - & - \\
\hline 3. & Flavonoids & - & + & + & + \\
\hline 4. & Saponins & - & - & + & + \\
\hline 5. & Phenolics & - & - & - & - \\
\hline 6. & Amino Acids & - & - & - & - \\
\hline 7. & Carbohydrate & + & + & & - \\
\hline 8. & Proteins & + & + & + & + \\
\hline 9. & Diterpenes & - & + & + & + \\
\hline
\end{tabular}

(+) Indicates 'Presence'; (-) Indicates 'Absence'

The total flavonoids content of the extracts was expressed as percentage of quercetin equivalent per $100 \mathrm{mg}$ dry weight of sample. The total flavonoids estimation of methanolic, aqueous and ethyl acetate extracts of rhizomes of $C$. amada showed the content values of 2.920, 2.717 and 2.895 respectively and TFC of methanolic and aqueous extract of $C$. caesia was 2.752 and 2.440 respectively Table4 \& Fig.1. Antioxidant activity of the samples was calculated through
DPPH assay. \% inhibition was calculated as an indicative of antioxidant potency. The higher the \% inhibition the better the activity. Ascorbic acid was taken as standard and the values were comparable with concentration ranging from 10 $\mu \mathrm{g} / \mathrm{ml}$ to $100 \mu \mathrm{g} / \mathrm{ml}$. A dose dependent activity with respect to concentration was observed Table 5 \& Fig 2 . In comparison to both the plant $C$. amada have higher antioxidant activity as comparison to $C$. caesia.

Table 4 Estimation of total flavonoids content of $C$. caesia and $C$. amada

\begin{tabular}{|c|c|c|}
\hline S. No & Extracts & $\begin{array}{c}\text { Total flavonoids content } \\
\text { (mg/ 100 mg of dried extract) }\end{array}$ \\
\hline \multicolumn{3}{|c|}{ C. caesia extracts } \\
\hline $\mathbf{1}$ & Methanol & 2.752 \\
\hline $\mathbf{2}$ & Aqueous & 2.440 \\
\hline \multicolumn{2}{|c|}{ C. amada extracts } \\
\hline $\mathbf{1}$ & $\begin{array}{c}\text { Ethyl } \\
\text { acetate }\end{array}$ \\
\hline $\mathbf{2}$ & Methanol & 2.895 \\
\hline $\mathbf{3}$ & Aqueous & 2.920 \\
\hline
\end{tabular}

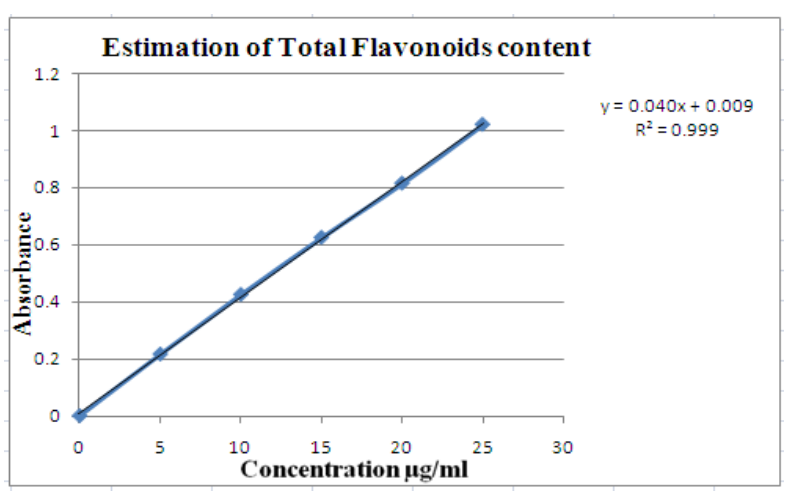

Figure 1 Graph of estimation of total flavonoids content 
Table 5 \% Inhibition of ascorbic acid, C. caesia and C. amada methanolic extract using DPPH method

\begin{tabular}{|c|c|c|c|c|}
\hline S. No. & $\begin{array}{c}\text { Conc. } \\
(\boldsymbol{\mu g} / \mathbf{m l})\end{array}$ & $\begin{array}{c}\text { Ascorbic acid } \\
\text { \% Inhibition }\end{array}$ & $\begin{array}{c}\text { C. caesia } \\
\text { \% Inhibition }\end{array}$ & $\begin{array}{c}\text { C. amada } \\
\text { \% Inhibition }\end{array}$ \\
\hline $\mathbf{1}$ & 10 & 40.92 & 8.26 & 11.94 \\
\hline $\mathbf{2}$ & 20 & 48.70 & 15.77 & 19.75 \\
\hline $\mathbf{3}$ & 40 & 73.48 & 24.65 & 41.8 \\
\hline $\mathbf{4}$ & 60 & 89.04 & 25.57 & 53.13 \\
\hline $\mathbf{5}$ & 80 & 90.20 & 28.48 & 60.49 \\
\hline $\mathbf{6}$ & 100 & 91.35 & 31.54 & 67.84 \\
\hline & IC 50 & 14.114 & 170.81 & 63.69 \\
\hline
\end{tabular}

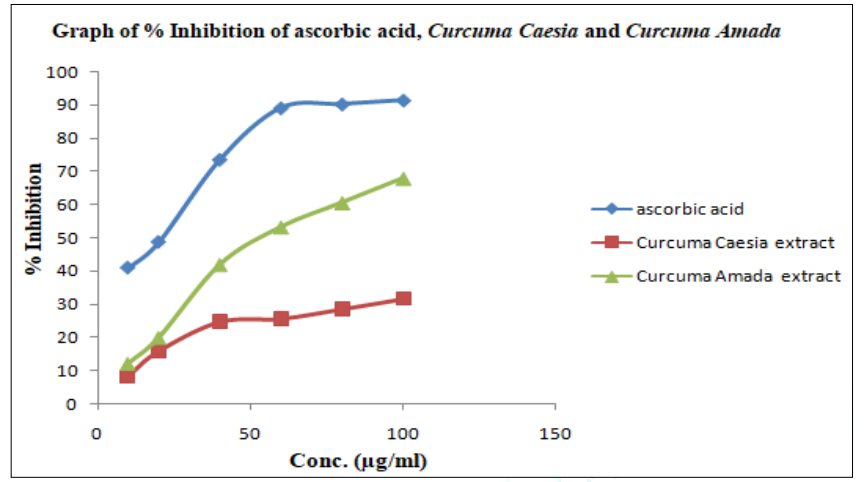

Figure 2 Graph of \% Inhibition of ascorbic acid, C. caesia and $C$. amada using DPPH method

\section{CONCLUSION}

It can be concluded that from present investigation The phytochemical investigation gave valuable information about the different phytoconstituents present in the plant, which helps the future investigators concerning the selection of the particular extract for further investigation of isolating the active principle and also gave idea about different phytochemical have been found to possess a wide range of activities. The potential antioxidant activity of organic extracts of $C$. amada and $C$. caesia rhizomes indicate its protective role against oxidative damage and as an important natural antioxidant. The curcumis of curcuminoide family found in spice turmeric is a potent antioxidant scavenging ROS and induced antioxidant response ${ }^{24}$. The extract due to its antioxidant activity could be utilized in pharmaceutical sector and food industries. Further research in this direction will be utilized for strengthening its real potential in various sectors.

\section{REFERENCES}

1. Chatopadhyay I, Biswas K, Bandhopadhyay U, Banerjee RK. Turmeric and Curcumin: biological actions and medicine of applications. Curr Sci 2004; 87:44.

2. Wealth of India: a dictionary of indian raw materials and industrial products. vol. 2. New Delhi: national institute of science communication and information resources, CSIR; 2001. p. 264.

3. Karmakar I, Dolai N, Bala A, Haldar PK. Anxiolytic and CNS depressant activities of methanol extract of Curcuma caesia rhizome. Pharmacologyonline 2011; 2:738-47.

4. Arulmozhi DK, Sridhar N, Veeranjaneyulu A, Arora SK. Preliminary mechanistic studies on the smooth muscle relaxant effect of hydroalcoholic extract of Curcuma caesia. J Herb Pharmacother 2006; 6:117-24.
5. Sarangthem K, Haokip MJ. Bioactive components in Curcuma caesia roxb grown in Manipur. The Bioscan 2010; 1:113-15.

6. Ghani A. Medicinal plants of Bangladesh: Chemical constituents and use. Asiatic Society 1998; 86: 290-291.

7. Verghese J. Mango-ginger- an exotic flavourant. Indian Spices 1990; 27: 15-16.

8. Shankaracharya NB.Mango ginger. Indian Cocoa. Arecanut Spices Journal 1982; 5: 78-80.

9. Husain A, Virmani OP, Popli SP, Misra,L N, Gupta M et al., Dictionary of Indian medicinal plants Lucknow: CIMAP 1992; 546.

10. Srivastava AK, Srivastava SK, Shah NC. Constituents of the rhizome essential oil of Curcuma amada Roxb from India. Journal of Essential Oil Research 2001; 13: 63-64.

11. Tamta A, Prakash O, Punetha H, Pant AK. Chemical composition and in vitro antioxidant potential of essential oil and rhizome extracts of Curcuma amada Roxb. Cogent Chemistry 2016; 2: 1168067.

12. Pushparani Devi H, Mazunder PB, Priyadarshini Devi L. Antioxidant and antimutagenic activity of Curcuma caesia Roxb, rhizome extracts. Toxicology Reports 2015; 2: 423-428.

13. Gupta VK. The wealth of India: First supplemented series (Raw materials) Vol. 2, New Delhi: Council of Scientific and Industrial Research, Pusa 2001; 259-260.

14. Desai VR, Kamat JP and Sinis KB. An immunomodulator from Tinospora cordifolia with antioxidant activity in cell free system, Indian Journal of Experimental Biology 2002; 114:713-720.

15. Dahanukar SA, Rege NN, Oak MA. In-vitro effect of Tinospora cordifolia on leukemia cell proliferation, Indian Journal of Pharmacology, 2004, 95, 130-135.

16. Middleton EJ, Kandaswami C, Theoharides TC. The effects of plant flavonoids on mammalian cells: Implications for inflammation, heart disease, and cancer. Pharmacological Reviews 2000; 52, 673-751.

17. Pokorny J. Natural antioxidants for food use. Trends in Food Science \& Technology1991; 2: 223-227.

18. Noguchi N, Niki E. Diet nutrition and health $20^{\text {th }}$ ed.. Papas M. P., FL: CRC Press 1999.

19. Mukherjee PK. Quality Control of Herbal Drugs, 2nd Edition, Business Horizons, 2007; 2-14.

20. Kokate CK. Ed. Practical Pharmacognosy, $4^{\text {th }}$ Edn., Vallabh Prakashan: 1994; 112:120.

21. Khandelwal KR. Practical pharmacognosy technique and experiments. 23rd Ed. Nirali Prakashan; 2005.

22. Kokate CK. Practical pharmacognosy. 4th Ed. Vallabh Prakashan; 1994.

23. Olufunmiso 00, Afolayan AJ. Phenolic content and antioxidant property of the bark extract of Ziziphus mucronata willd. Subsp. mucronata willd, BMC Complement Alternative Medicine, 2011; 11:130.

24. Elsayed AI. The curcumin as an antioxidant natural herb with emphasize on its effects against some diseases. International Journal of Applied Biology and Pharmaceutical Technology 2016; 7:26-40. 